\title{
Eco-innovative food in Brazil: perceptions from producers and consumers
}

\author{
Marilia B Bossle ${ }^{1 *}$, Marcia D de Barcellos ${ }^{1}$ and Luciana M Vieira ${ }^{2}$
}

\author{
* Correspondence: \\ marilia.bossle@ufrgs.br \\ ${ }^{1}$ Federal University of Rio Grande \\ do Sul, Post-Graduate Programme \\ in Management (PPGA/UFRGS) - \\ Porto Alegre, (90010-460) RS, Brazil \\ Full list of author information is \\ available at the end of the article
}

\begin{abstract}
The main focus of this paper is to analyse the production and consumption for eco-innovative food in Brazil. The research can be divided in two parts: the first, focusing in the supply-side, aims to identify food companies' motivation to adopt eco-innovation, and the second, in the demand-side, to investigate consumer values and attitudes towards eco-innovation. In order to analyse the supply-side, an exploratory phase has been conducted with 13 in-depth interviews with firms and organizations that work with eco-innovative food, green certifications and green food associations. The analysis of the demand-side was carried out through an exploratory phase, with 42 interviews in green and organic fairs and street markets along with a Survey with 401 consumers in traditional Organic Street Markets in Porto Alegre, Brazil. The quantitative data from this stage was analysed with SPSS (univariate statistics). Results indicate that the companies' mission and strategy are important drivers for the adoption of eco-innovations in the food sector. Technology is an essential input for the supply side, and can act as an important driver to increase the supply of sustainable food, to reduce losses, and to improve environmental sustainability. The eco-innovative market has a great potential to grow and become more competitive, although some barriers still need to be transposed: clearer regulations, logistics, high quality manpower and production of more convenient products for consumers. Results from the analysis of consumers indicate the presence of egalitarian values, and positive attitudes towards environment and technological progress, as well as a positive attitude and intention to buy eco-innovative food. Additional findings points out towards a certain belief on behalf of Brazilian consumers that technology can be a determinant of relevant aspects of eco-innovative foods. This research is of particular academic value, by adding empirical evidence about the relationships that rule how values and general attitudes influence attitudes towards eco-innovative food in the Brazilian food consumption context. Managerial implications are related to the need for companies to remain competitive and profitable, and innovation and environmental sustainability can be used as an alternative to mitigate environmental risks derived from the company's activities.
\end{abstract}

Keywords: Eco-innovative food; Personal values; Innovation; Sustainability; Conscious consumer

\section{Springer}

(c) 2015 Bossle et al.; licensee Springer. This is an Open Access article distributed under the terms of the Creative Commons Attribution License (http://creativecommons.org/licenses/by/4.0), which permits unrestricted use, distribution, and reproduction in any medium, provided the original work is properly credited. 


\section{Background}

Although economic change begins in the supply-side (Schumpeter, 2008), consumers' demand is a relevant driver for changes in products and processes. It is a cycle, where in order to compete and grow, an innovative company must act in a technological, technical, policy, and management environment that allows an innovative approach, whereas market conditions must also be ensured.

The increase of consumers' awareness towards environmental concerns, as well as other social and governmental pressures claim the development of new products with less environmental impact by manufacturers (Bocken et al. 2011). To achieve environmental sustainability and do not neglect goals related to economic growth, innovation in green products can be a key factor for companies (Dangelico and Pujari 2010).

The Organization for Economic Co-operation and Development (OECD) defines eco-innovation as "the development of products (goods and services), processes, marketing methods, organizational structure, and new or improved institutional arrangements, which, intentionally or not, contribute to a reduction of environmental burdens in comparison with alternative practices "(Organization for Economic Cooperation and Development OECD 2009).

Considering that consumers depend on companies to access the supply for their needs and the growth of this new concept, the research question of this paper arises: From the point of view of consumers and producers, what is the perspective of an eco-innovation market for the food sector in Brazil? The main focus of this paper is to analyse the production and consumption of eco-innovative food in Brazil.

The analysis of the production and supply-side aims to identify main motivations for eco-innovation, trends and characteristics of this market using in-depth interviews. These results, combined with the findings from the demand-side, will contribute to increase comprehension about this expanding market in an emerging country. Considering that sustainable consumption is a recent subject in Brazil, identifying the main characteristics of this market will benefit companies of the food sector, both industry and retailing. It is also important to emphasize that Brazil is one of the major food producer and exporter worldwide although the mass scale production is main production pattern.

The analysis of the consumer-side aims at investigating conscious consumption behaviour of food in Brazil, specifically, to verify the relationship among personal values, attitudes towards the environment and technology, and attitudes and consumer behaviour towards eco-innovative food. This second phase integrates an exploratory and descriptive phase with consumers.

Attitudes represent a disposition to respond favourably or unfavourably to an object, person, institution or event (Ajzen 1988). Values are related to social norms (or behaviour rules), and reflect an internal reference to what has been considered good, beneficial, important, desirable. It has been stated by the literature a great impact of cultural values on consumers' attitudes towards food consumption (Thøgersen and Beckmann 1997). In addition, personal values affect (usually positively) people's environmental behaviour, purchase intention and behaviour towards ecological food, e.g. organic food (Grunert 1993; Grunert and Juhl 1995; Hopper and Mccarl 1991; Schwartz 1992).

The food sector is a good example for studying the integration between innovation and sustainability for several reasons. Traditionally, the food sector has been oriented towards commodities' production, however, improvement of quality and efficiency in 
the process are among the main features for increasing values for the sector. Finally, increasing integration in the food chain emphasizes the relevance of studying "from production to consumption". Innovation is driven by a greater operational efficiency, but also boosted by the final user's demand, whose concern with food safety, health, animal welfare, environmental issues has increased (Grunert et al. 2005).

Considering the Schumpeterian concept, an innovation needs to be commercially feasible, therefore, the understanding of the end consumer is an important component when analysing industry. Consumers' perception is an important driver to determine how agents from the food chain can persevere in the market. Trends about how consumers value food products are an important contribution to develop the strategy of food companies (Grunert et al. 1993).

In Brazil, the food sector comprises 32,000 companies and employs 1.63 million workers (Brazilian Food Industry Association ABIA 2014). Therefore, for the adoption of a new way of production, and to aggregate environmental sustainability and innovation (and eco-innovation), it is necessary to integrate the chain to ensure the provision of adequate raw materials (production), food processing and supply (food and packaging industry) to reach the consumers who are increasingly more aware in relation to the health and convenience. Furthermore, the environmental impact and the level of emissions from the food sector are considered high (Demirel and Kesidou 2011).

This article is structured as follows, after this introduction, in section 2 the theoretical background is described, section 3 explains the method employed, followed by section 4 , where the main results are described and discussed. In section 5, the main conclusions are drawn.

\section{Eco-innovation, attitudes and values: from production to consumption}

Eco-innovation is the technological and organizational innovation related to the implementation of the sustainable development (Faucheux et al. 2006). Applying and assimilating innovation and sustainability in business management are crucial to achieve sustainability main objectives (social, economic and environmental) (Korhonen 2001). Eco-innovation is also conceptualized as a redefinition of innovation, such as the types of innovation defined by OECD (product, process and organizational) that are useful, but not enough for studying issues of sustainable development embedded in innovation (Rennings 2000).

Eco-innovations hold specific features, such as the importance of creating links and positive trade-offs between the attribute of environmental protection and other critical factors of competitive products and services, such as style, design, price and performance. Furthermore, eco-innovations that succeed are highly dependent on greater participation of stakeholders in their development. Accordingly, they tend to emerge from cooperation between different entities, in addition to the constitution of partnerships among public sector, academia and private sector (Carrillo-Hermosilla et al. 2010).

Companies are considered as the main source of social and environmental problems in society. Therefore, more restrictive regulatory policies must be developed by governmental and non-governmental organizations to regulate business companies (Azzone and Noci 1998; Schaltegger and Wagner 2011). Eco-innovation has become an important strategic tool for achieving sustainable development, not only for its potential to 
reduce environmental impact, but also for improving competitiveness of firms and countries that eco-innovate (Chang 2011; Kesidou and Demirel 2012).

Beyond the importance of including environmental concepts in corporate strategy, environmental awareness of consumers is also a relevant variable for production and consumption of environmental friendly products (Horbach 2008). Although eco-innovations can be of lower acceptance (Halila and Rundquist 2011), the start for developing, producing and marketing a new green product is also related to its potential to succeed in the market (Dangelico and Pujari 2010). The perception of value of consumers about the insertion of environmental issues in the development of products is a critical issue. Adoption and diffusion of environmental innovative products depends on consumer's evaluation (Oltra and Jean 2009).

Within this context, values and consumer's attitudes can influence on the purchase of eco-innovative food. Consumer's concern towards ethical, social and environmental issues, but at the same time their demand for varied and affordable food, provides an important and relevant opportunity for further research on the relationship between specific attitudes towards eco-innovative food (AtEco) and its direct antecedent, i.e., attitudes towards the environment and nature (AtEnviro). Additionally, it is reasonable to infer that attitudes towards technology (AtTechno), that reveals consumer perceptions about the prevailing type of food supply in Western societies, e.g., industrial food production systems, should also influence (possibly negative) on consumer's attitudes towards eco-innovative food. Elsewhere, it is of great importance to incorporate the study of consumer values (collective and individual) for analysing consumer's attitudes, once values are the main antecedents of attitudes, and allows the creation of the hierarchical value-attitudes model.

Due to the profound impact of personal values on food consumption (Thøgersen and Beckmann 1997), their possible influence on conscious purchase of eco-innovative food is the starting point in the phase of the study with consumers. The model in Figure 1 first assumes direct causal relationships between: a) egalitarian values of consumers and their attitudes towards environment and nature ("Collectivism - AttEnviro"); and b) self-promoting values and attitudes towards technological progress ("Individualism AttTechno").

Understanding how these attitudes influence conscious purchase of eco-innovative products is particularly important from the strategic point of view for companies when developing new products, as it reflects the contradictory impact of the influence of consumers' pro-technological and pro-environment attitudes in relation to consumption of these foods. Preliminary studies indicate the validity of this model (Krystallis et al. 2012; Perrea et al. 2014), what motivates the research of the same model in the Brazilian context.

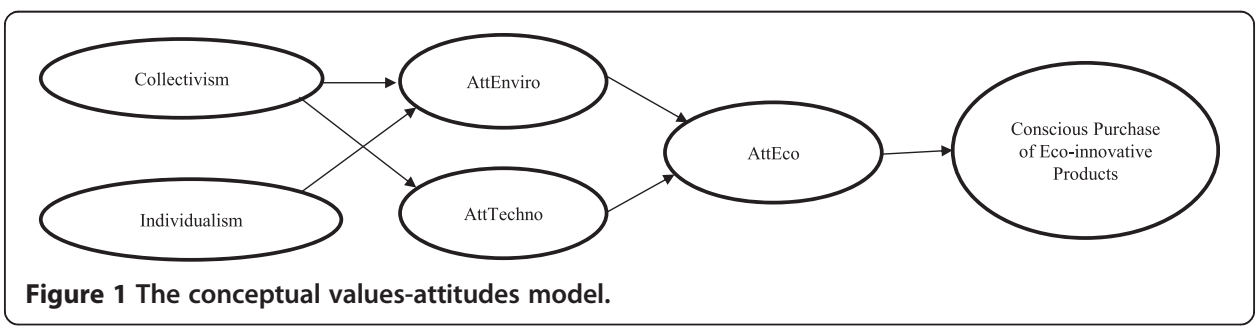


Therefore, for surviving in the market, producers and sellers must produce products with aggregated value for consumers, in a way that they perceive that it is worthwhile to pay an extra premium price, which is higher than conventional products due to its higher production costs (Grunert et al. 1993). The existence of a potential market willing to pay for an innovation is the main condition to invest in an innovation (Dosi 1988).

Considering uncertainty as a particular characteristic of innovation, a multi-perspective study, analysing consumers and companies, can be of great importance to the sector. Understand how consumer values and attitudes affect consumption behaviour may reduce uncertainty, and understand the potential acceptance of a product, can reduce risks related to eco-innovators.

In addition, interaction between the main actors is expected due to the systemic nature of innovation and can be a key factor for companies to adapt its activities to the given environmental conditions (Asheim and Gertler 2005; Ettlie 1983; Fagerberg 2005).

Finally, Azzone and Noci (1998) highlight the role of the government to develop new campaigns, aiming at improving environmental and social awareness. To justify financial investments and to turn feasible to implement innovative environmental solutions, it is important that market awareness arises. The method applied in this research is described in the next section.

\section{Method}

The research can be divided in two parts, one focusing in the supply-side, to identify eco-innovation motivations, and other in the demand-side, to investigate consumer values, attitudes and behaviour towards eco-innovative food.

\section{First phase: supply-side}

To achieve the objectives of this study, in the first phase we conducted a qualitative analysis using a documental survey and 13 in-depth interviews with firms and organizations involved with the eco-innovative food market, green certifications and green food association.

A qualitative research approach is important to obtain deeper information from relevant stakeholders in the food industry. The research protocol consisted of open questions on the following variables: identifying main drivers for eco-innovation, main trends and specific characteristics of this market from their point of view. The interviewees were selected based on their relevance as key stakeholders with different perspectives of the food industry in Brazil, see Table 1 for details. The 13 interviews were recorded and transcribed. Data collection was conducted from March 2013 to January 2014 and followed a prepared script based on the research objectives.

To analyse the data, the technique of content analysis were applied, in which the content of interviews was divided into the following categories: Companies' motivation to work with eco-innovation, importance of technology in food production, influence of Regulations, and Market, always related to eco-innovative food products.

\section{Second phase: consumers}

Considering that the level of environmental concern should be associated with a willingness to act in the same way (Roberts and Bacon 1997), and due to the target group 
Table 1 Interviewee's characteristics - supply-side

\begin{tabular}{lll}
\hline Interviewee & Business segment & Details \\
\hline Ind1 & Food Industry: Producer & Organic food for young children \\
Ind2 & $\begin{array}{l}\text { Food Industry: Producer and } \\
\text { retailer }\end{array}$ & $\begin{array}{l}\text { Agriculture, chicken, convenience products, producer of } \\
\text { antibiotic free poultry }\end{array}$ \\
Ind3 & Food Industry: Producer & Alternative poultry production \\
Ind4 & Food Industry: Producer & Agro ecological Industry - medicinal and food plants \\
Ind5 & Food Industry: Producer & Organic bread \\
Ind6 & Food Industry: Producer & Producer of biodynamic rice \\
Ind7 & Food Industry: Producer & Organic juice and oils \\
Ret1 & Food retailers & Supermarket specialized in organic, natural, and health products \\
Ret2 & Food retailers & Sustainable food - grocery store and restaurant \\
Ret3 & Food retailers & Organic tea \\
Ret4 & Food retailers & Organic Food \\
Cert1 & Certifier's organizations & Organic certification organization \\
Cert2 & Certifier's organizations & Food traceability \\
\hline
\end{tabular}

for this study (conscious consumer), the data collection with consumers was carried out in sustainable food retails outlets, e.g. organic street markets or sustainable food fairs.

The ecologically conscious consumer considers the impact on the environment when purchasing goods and services (Roberts and Bacon 1997). Environmental consumption occurs when consumers prefer products that do not damage the environment during the production, distribution, consumption or final disposal (Portilho 2005). Additionally, pro-environmental behaviour infers do not cause harms or even improve environment's condition (Steg and Vlek 2009) and entails that the consumer's concern will involve a more socially and environmentally responsible manner of acting (Balderjahn et al. 2013).

\section{Exploratory phase}

To analyse the demand-side, we first undertook an exploratory phase, with 42 face to face interviews in three weekly organic street markets in Porto Alegre and São Paulo, Brazil, and in a fair that is held annually in Porto Alegre, to promote organic, sustainable and solidarity-base food products.

The protocol included the following variables, which were the same used for the analysis: overall perception on sustainability; supply and relationship between technology $\mathrm{x}$ sustainability; consumption: frequency of purchase and consumption; attributes; food origin; motivation for purchase and consumption of sustainable food. The results of the interviews undertaken for the exploratory phase were analysed and contribute to understand the conscious consumption of eco-innovative food. A brief description of the main results is presented below.

\section{Overall perception on sustainability}

Most respondents said that human beings are not in balance with nature. Actions taken both individually and collectively, as well as actions taken by companies, can impact severely on the environment. Although consumers were optimistic, as they perceived a growing awareness regarding the relationship between sustainability and healthy eating, 
the "holistic view" is still missing, since only single actions are taken, by a minority. Consumers also depend a lot on companies for supplying green products, and complained that most decisions taken by companies don't consider neither the environment, nor consumer wishes.

\section{Supply and relationship between technology $\mathrm{x}$ sustainability}

In relation to the supply of eco-innovative food, it was noticed high variability in responses, whereas most of consumers who responded that the supply is sufficient relates to consumers who purchase in Organic street markets. In other words, there is a satisfactory supply for the product in natura, e.g. fresh fruits and vegetables, but other eco-innovative products with higher added value for the producer and convenience for consumers are still missing.

In relation to technology, generally, respondents considered technology essential for increasing the production and supply of healthy, organic and eco-innovative food for a larger number of consumers. Most respondents had a positive attitude towards technology (only 6 consumers think that technology makes food production and processing less sustainable).

\section{Consumption}

Among the sample from this exploratory phase, we can infer that when consumers start to consume organic products, they acquire the habit, especially for those who purchase in Organic Street Markets, and tend to become regular and loyal customers.

Consumers reported that they tend to establish a relationship with sellers from the organic street markets, and that they trust in the information provided by sellers, who became the main source of knowledge about organic food and production. In average, Brazilian consumers seek for healthier food when purchasing organic food, their main motivation is to avoid ingestion of poisons, pesticides, and to prevent diseases.

\section{Descriptive phase}

Further, a descriptive phase was performed, and it was conducted a Survey with 401 consumers, to analyse attitudes, intention and buying behaviour of conscious consumers in traditional Organic Street Markets in Porto Alegre, Brazil. The quantitative study with consumers aimed at identifying values, attitudes and conscious consumers' purchase in relation to embody innovation and technology in the production of eco-innovative food. Results from this phase are compared with data from the industry to follow the "from production to consumption" approach of this study. We choose the organic street markets by convenience, to ensure that the sample is composed of conscious consumer of eco-innovative food, e.g. organic food. Eco-innovative food was defined in the questionnaire as follow: "Eco-innovative food are those endowed with ethical/social/ environmental appeals, such as organic food, meat or eggs from free range animals, fair trade, family agriculture, among others".

The questionnaire applied in this phase included the following sections: 1) first, an initial filter question, to ensure that the respondent was a conscious consumers; 2) second section to investigate personal values, 21 - item version (portrait value questionnaire - PVQ) from Schwartz (1992) measured on a 6-point similarity scale with 
end-points 1 = "not like me at all" to $6=$ "very much like me"; 3 ) third section refers to attitudes towards technology (5 items used by Hamstra, 1991), environment and nature (using a reduced 5-item version of the New Environmental Paradigm (NEP) scale by Dunlap et al. 2000), and technological progress (5 items by Beckmann et al. (2001), measured on 7-point Likert-type agreement scales, with end-points 1 = "strongly disagree" to 7 = "strongly agree"; 4) in the fourth section, attitudes towards food production, measured on a 7-point Likert type, in a 5 items scale based on Lindeman and Väänänen (2000); 5) Attitudes and conscious purchase behaviour towards eco-innovative food. For attitudes, a semantic scale were used, and questions to identify consumption of this products; 6) Demographics.

Professional researchers hired to carry out the data collection process, which was performed in-person in September 2013 in four Organic Street Markets in the city of Porto Alegre.

Attitudes are determined by a combination of personal values (egalitarian or selfish) and general views on environment and nature (affective attitude) and technological progress (cognitive attitude). The quantitative data from this stage was analysed with SPSS (Statistical univariate). The final sample included 401 respondents. The sample's profile is shown in the next section.

\section{Demographics}

The demographic data are shown in Table 2.

Table 2 Demographics

\begin{tabular}{llll}
\hline Variable & Level & Frequency & Percent \\
\hline Gender & Female & 259 & $64,6 \%$ \\
& Male & 142 & $35,4 \%$ \\
& Valid & 401 & $100,0 \%$ \\
Income (per month) & Less than €414 & 36 & $9 \%$ \\
& $€ 415-€ 622$ & 47 & $12 \%$ \\
& $€ 623-€ 1,036$ & 95 & $25 \%$ \\
& $€ 1,037-€ 2,073$ & 104 & $27 \%$ \\
& $€ 2,074-€ 4,146$ & 72 & $19 \%$ \\
& $>€ 4,146$ & 33 & $9 \%$ \\
Education & Valid & 387 & $100 \%$ \\
& Primary (Basic education) or less & 17 & $4,3 \%$ \\
& Secondary (High school) & 140 & $35,4 \%$ \\
& Superior (University degree) or more & 239 & $60,3 \%$ \\
& Valid & 396 & $100 \%$ \\
& Married & 163 & $41 \%$ \\
Marital status & Not married, but living together & 87 & $22 \%$ \\
Not married, living alone & 99 & $25 \%$ \\
& Divorced & 25 & $6 \%$ \\
& Widowed & 24 & $6 \%$ \\
& Valid & 398 & $100 \%$ \\
\hline
\end{tabular}


Regarding the age of the respondents, the average age is 43.6 and median is 42 . The majority of the sample population was female (64.6\%). In Porto Alegre, there are 1,409,351 inhabitants: 54\% women and 46\% men (Brazilian Institute of Geography and Statistics - IBGE 2013). The level of education of the consumers is high, with $60.3 \%$ with a University degree or higher. Most of the sample lives together with other people, and have a median income per month. In the next section, the main results are described.

\section{Results}

In this section, the main results from the supply-side are presented, followed by the descriptive analysis of consumers' research.

\section{Supply-side}

The main findings from in-depth interviews with relevant representatives from the supply-side are presented in this section. The analysis was categorised as follows: first, the main motivations stated by the companies to adopt eco-innovation in the food sector; then the importance of technology for food production, importance and impact of regulations, and finally, trend and perspectives for this Market, especially in a emerging country.

\section{Companies' motivation to work with eco-innovation}

Representatives from companies stated that they were moved by their own mission and philosophy for work with a product that provides health and welfare for consumers, and deny the use of pesticides in the process, especially for organic producers. Another great driver is to establish food chains that work with those principles of innovation and sustainability. The food sector also face a commercial motivation to this market, whose good's supply is lower than its demand (Ind7).

The motivation was also related to health issues, since healthier food has a direct relationship to public health scores of obesity, hypertension, among others. Healthier and more sustainable food must be produced in a more controlled environment, using the right amount of sugar, salt, and, overall, with no pesticides (Cert2).

They were also motivated to develop new products that were not available in the eco-innovative market yet. The importance of the food chain was also highlighted in this case, given that in some cases is necessary to develop suppliers, food industry and retailers also have this responsibility (Ind2).

\section{Importance of technology in food production}

Technology was reported as an essential input for the supply side, and as an important driver to increase the supply of sustainable food, to reduce losses, and, to improve environmental sustainability. It can also be used to improve packages, which must be ecological, but also practical, modern, and attractive.

It is an important driver to increase the adoption of more sustainable processes in food industry, given that technology and quality in the process has a direct relationship in the food industry (Ind6). Innovation in the food sector is also driven by an unique capability of the company and motivated by a willing to differentiate and to add value for the product. 
Usually innovation is more common in bigger and more mature firms, and even when the ecological and sustainable impact is not intentional, they contribute for eco-innovators food chain. Producers are very focused in ecological issues, but not in innovation and commercial skills to improve the market (Ret4).

\section{Influence of regulations}

Regulations and legislations were seen as incomplete and ineffective, since Brazilian legislation for 'organics', for example, mainly focus in fruits and vegetables, wherein other products remain uncovered by an organic or other type of eco-innovative background. Furthermore, this is a complaint from the supply-side, because it is difficult to communicate to the market about other health and eco-innovative products. Besides this, it was highlighted that there are much more advertising on junk food than on sustainable food in the market.

\section{Market}

The market has a great potential to grow and become more competitive. The interviews pointed out that some barriers still need to be transposed: logistics, high quality manpower and more convenient products for consumers.

\section{Consumers}

Results from the survey with consumers are presented in this section. First, univariate statistics were applied, in order to measure attitude and value items. Next, we investigated the values and attitudes structure by an exploratory factor analyses (EFA). The principal component analysis with Varimax rotation was applied. KMO (Keiser-MeyerOlkin) score and Bartlett's test were verified (Hair et al. 1998).

In order to verify if there is any relation between some groups of variables identified in the study, a regression analysis was performed. The general purpose of multiple regressions is to learn more about the relationship between several independent or predictor variables and a dependent or criterion variable. Therefore, the same pool of attitudes and values identified by the EFA was used as independent variables (predictors), and consumption of eco-innovative food per week was used as the dependent variable. Educational level, gender, age and marital status were used as control variables.

To assess the internal consistency of the data collection instrument, Cronbach's alpha coefficients were measured for each of the constructs (see Tables 3 and 4), and satisfactory internal consistency was found, almost all greater than 0.6 (Hair et al. 1998). Cronbach's alpha score for the personal value "Universalism/benevolence", a factor extracted from exploratory factor analysis, was 0.56 , and need further investigation. Cronbach's alpha scores for the three attitudinal scales were satisfactory to very high ( 0.78 for the attitudes towards environment and nature, 0.82 for the attitudes towards technological progress; 0.82 for Attitudes towards food production; 0.84 for attitudes towards eco-innovative food; and 0.94 for Attitude towards Industrial production).

\section{Values and attitudes}

Values and attitudes were then analysed, by means of an exploratory factor analysis to test their structure (Table 3). All attitudes variables presented very consistent factor 
Table 3 Exploratory factor analysis of the attitude scales

\begin{tabular}{|c|c|c|c|}
\hline ATTITUDES & Loading & Mean & S.D. \\
\hline Attitude towards environment and nature & & 6.42 & \\
\hline Humans are severely abusing the environment & 0.798 & 6.68 & 0.726 \\
\hline $\begin{array}{l}\text { The balance of nature is fragile to withstand the impacts of modern industrial } \\
\text { nations* }\end{array}$ & 0.747 & 6.57 & 0.867 \\
\hline The so-called "ecological crisis" facing humankind does not get proper attention* & 0.794 & 6.38 & 1.054 \\
\hline The Earth is finite. with little space and limited resources & 0.576 & 6.23 & 1.260 \\
\hline $\begin{array}{l}\text { If things continue on their present course. we will soon experience a major } \\
\text { ecological catastrophe }\end{array}$ & 0.812 & 6.25 & 1.231 \\
\hline Attitude towards technological progress Cronbach alpha: $\mathbf{0 . 8 2}$ & & 6.07 & \\
\hline $\begin{array}{l}\text { Many food manufacturers are more interested in making money than in the } \\
\text { nutritional quality of its products }\end{array}$ & 0.726 & 6.29 & 0.974 \\
\hline Modern production of food removes vitamins and minerals from food & 0.812 & 6.16 & 1.004 \\
\hline The food industry is little concerned about the nutritional value of their products & 0.850 & 6.09 & 1.035 \\
\hline Most foods are so processed that they lose nutritional value & 0.819 & 6.17 & 0.997 \\
\hline The vast majority of food presents risks when consumed & 0.649 & 5.65 & 1.336 \\
\hline \multicolumn{2}{|l|}{ Attitude towards Industrial production Cronbach alpha: 0.941} & 5.08 & \\
\hline $\begin{array}{l}\text { The degree of civilization can be measured from the degree of technological } \\
\text { development }\end{array}$ & 0.901 & 5.17 & 1.747 \\
\hline $\begin{array}{l}\text { New technological inventions and applications make up the driving force of } \\
\text { progress of society }\end{array}$ & 0.905 & 5.19 & 1.669 \\
\hline $\begin{array}{l}\text { In Brazil we are probably better off than ever thanks to the tremendous progress in } \\
\text { technology }\end{array}$ & 0.886 & 4.72 & 1.845 \\
\hline $\begin{array}{l}\text { Throughout the ages. technological know-how has been the most important } \\
\text { weapon in the struggle for life }\end{array}$ & 0.925 & 5.12 & 1.700 \\
\hline $\begin{array}{l}\text { Because of the development of the technology we will be able to face up to the } \\
\text { problems of tomorrow's society }\end{array}$ & 0.886 & 5.18 & 1.799 \\
\hline \multicolumn{2}{|l|}{ Attitudes towards food production Cronbach alpha: 0.817} & 6.79694 & \\
\hline \multicolumn{4}{|l|}{ It is important that the food I eat on a typical day... } \\
\hline Has been prepared in an environmentally friendly way & 0.750 & 6.76 & 0.591 \\
\hline Has been produced in a way which has not shaken the balance of nature & 0.738 & 6.78 & 0.527 \\
\hline Is packaged in an environmentally friendly way & 0.801 & 6.72 & 0.599 \\
\hline Bring benefits to the local community & 0.680 & 6.75 & 0.521 \\
\hline $\begin{array}{l}\text { Has been produced in a way that is guaranteed that animals have not } \\
\text { undergone pain }\end{array}$ & 0.667 & 6.74 & 0.669 \\
\hline $\begin{array}{l}\text { Has been produced by companies that guarantee fair working conditions to } \\
\text { their employees }\end{array}$ & 0.616 & 6.90 & 0.339 \\
\hline Has been produced without the use of child labor and/or slave labor & 0.649 & 6.93 & 0.297 \\
\hline Attitudes towards eco-innovative - food Cronbach alpha: 0.84 & \multicolumn{3}{|c|}{6.94763} \\
\hline Negative/Positive & 0.913 & 6.94 & 0.366 \\
\hline Harmful/Beneficial & 0.885 & 6.97 & 0.258 \\
\hline Unsatisfied/Satisfied & 0.739 & 6.93 & 0.458 \\
\hline Unpleasant/Pleasant & 0.895 & 6.96 & 0.271 \\
\hline
\end{tabular}

*Originally, reversed scales, but unreversed for Brazilian questionnaire.

loading scores, so it was only necessary to remove one of the items in the scale "Attitudes towards eco-innovative food" for further analysis.

The scale "Attitude towards environment and nature", presented internal consistency, and the resultant factor analysis kept all the 5 items, with satisfactory factor loadings 
Table 4 Exploratory factor analysis of the personal values

\begin{tabular}{|c|c|c|c|}
\hline Item description & Loading & Mean & S.D. \\
\hline Traditional and Moral Cronbach alpha: $\mathbf{0 . 6 8}$ & & 4.88 & \\
\hline Security & 0.587 & 5.26 & 0.799 \\
\hline Conformity & 0.828 & 4.51 & 1.192 \\
\hline Tradition & 0.810 & 4.88 & 1.115 \\
\hline Adventure Cronbach alpha: 0.715 & & 4.18 & \\
\hline Stimulation & 0.742 & 4.30 & 1.20 \\
\hline Hedonism & 0.700 & 5.40 & 0.76 \\
\hline Achievement & 0.787 & 3.53 & 1.32 \\
\hline Power & 0.685 & 3.49 & 0.96 \\
\hline Universalism/benevolence Cronbach alpha: 0.559 & & 5.57 & \\
\hline Benevolence & 0.684 & 5.749 & 0.379 \\
\hline Universalism & 0.764 & 5.453 & 0.502 \\
\hline Self-direction & 0.694 & 5.516 & 0.580 \\
\hline
\end{tabular}

(KMO 0.82, Barlett Test 597.553, sig. 0.000, 56.31\% of explained variance). The high mean of this construct (6.42), allow us to infer that consumers in the analysed sample are very aware of the environment.

Unexpectedly, "Attitude towards technological progress" (KMO 0.843, Barlett Test 716.83, sig. $0.000,60.02 \%$ of explained variance), also presented high means among conscious consumer, what confirm the results from the exploratory phase. Brazilian consumers believe that technology can be a positive determinant of the production of healthier and more environmental friendly food.

Attitude towards industrial production (KMO 0.853, Barlett Test 1262.56, sig. 0.000, $82.29 \%$ of explained variance) presented the highest reliability among attitude scales in the Brazilian, and the lowest mean (5.08), but still positive. This result ratifies that for Brazilian consumers, sustainability and industrial food production can coexist, somehow a different result from what is usually found in Europe. For the majority of Europeans, industrial food production is related to technology (reflecting consumer perceptions about the industrial food production systems that prevail as source of food supplies to Western societies) (De Barcellos et al. 2012; Krystallis et al. 2012; Perrea et al. 2014).

All the 7-item of Attitudes towards food production were kept (KMO 0.798, Barlett Test 964.606, sig. 0.000, 49.37\% of explained variance). In the scale Attitudes towards eco-innovative food (KMO 0.775, Barlett Test 1005.33, sig. 0.000, 74.12\% of explained variance), the variable represented by the first statement of the semantic scale (bad/ good) had to be removed due to its very low reliability score. The mean value of 6.95 indicates a high positive attitude towards eco-innovative food among consumers from the sample.

Generally for attitudes, the loadings were quite satisfactory, indicating that the items were highly correlated with the factor. Next, Table 4 presents the results of the exploratory factor analysis of the personal values, using PVQ original dimensions (KMO 0.685, Barlett Test 858.96, sig. $0.000,60.457 \%$ of explained variance.

Similarly to the findings of de Barcellos et al. (2012), the exploratory factor analysis of the personal values items shows that not all the variables behave or aggregate as the 
original scale. When analysing and interpreting the 10 value dimensions of the PVQ, only three items that belong to collectivistic values have been aggregated into one factor, and those are "Conformity", "Security" and "Tradition". Based on the resulting characteristics of the items in this group, and considering the similar result found by de Barcellos et al. (2012), this new factor was named "Traditional and Moral Values" representing more a traditional behaviour.

Likewise, four items that belong to individualistic values, "Stimulation", "Achievement", "Hedonism" and "Power" were also aggregated into a new factor, named "Adventure", representing a more adventurous way of life. Finally, the original items from the dimensions "Universalism" and "Benevolence" and "Self-Direction" from the PVQ were aggregated in a new factor, "Universalism/Benevolence". Mean value for this factor was the highest (5.57), followed by "Traditional and Moral" values (4.88) and "Adventure" values (4.18), indicating that for the Brazilian respondents collective values seem to overtake individual ones.

Afterward, we present the multiple regression analysis that was applied to investigate relationships between attitudes, personal values and consumption of ecoinnovative food.

Regression analysis between attitudes and values and consumption of eco-innovative food To identify the influence of independent variables in the consumption of eco-innovative food (dependent variable: consumption per week), a regression analysis was applied (Table 5). The main associated factor to eco-innovative food consumption is attitudes towards eco-innovative food. So for every unit increase in attitudes towards eco-innovative food, a 0.902 unit increase in eco-innovative food consumption is predicted, holding all other variables constant. In addition, attitudes towards food production, intention to buy eco-innovative food, frequency of purchase, Education and Adventure values also influence the consumption of eco-innovative food, the later with a negative impact.

A 0.799 unit increase in attitudes towards food production will be expected for each unit increase of eco-innovative food consumption. Every unit increase in intention to buy eco-innovative food and frequency of purchase is expected a 0.672 and 0.439 , respectively, point increase in the eco-innovative food consumption per week.

"Adventure values" has a negative impact into eco-innovative consumption and for each increase in the adventure values, consumption will decrease by 0.354 . Among the investigated socio-demographic variables, only Education is significant in this model, meaning that from one educational category to the next higher one (and keeping all other variables constant) will increase consumption of eco-innovative food products in 0.364 .

\section{Discussion}

Following the main goal of this study that was to draw the perspectives of the ecoinnovative market in the food sector in Brazil we can see some peculiarities in this market, both from the supply and the consumers' side. Although companies seek economic profitability, and use innovation in green products to achieve environmental sustainability (Dangelico and Pujari 2010; Korhonen 2001), their motivation to invest in the eco-innovative market is more related to personal motivations of its founders. These personal inspirations are disclosed in their own mission and philosophy to provide 
Table 5 Regression analysis

\begin{tabular}{|c|c|c|c|c|c|}
\hline \multirow[t]{2}{*}{ Model } & \multicolumn{2}{|c|}{$\begin{array}{l}\text { Unstandardized } \\
\text { coefficients }\end{array}$} & \multirow{2}{*}{$\begin{array}{l}\text { Standardized coefficients } \\
\text { Beta }\end{array}$} & \multirow[t]{2}{*}{$\mathrm{t}$} & \multirow[t]{2}{*}{ Sig. } \\
\hline & B & Std. Error & & & \\
\hline Constant & -13.197 & 3.587 & & -3.679 & .000 \\
\hline Traditional_Moral & -.108 & .123 & -.047 & -.881 & .379 \\
\hline Adventure & -.354 & .135 & -.147 & -2.610 & .009 \\
\hline Universalism_Benevolence & .148 & .257 & .029 & .575 & .566 \\
\hline Intention to buy eco-innovative food & .672 & .199 & .162 & 3.376 & .001 \\
\hline Purchase_freq & .439 & .080 & .266 & 5.498 & .000 \\
\hline Attitudes towards eco-innovative food & .902 & .382 & .113 & 2.359 & .019 \\
\hline Attitudes towards food production & .799 & .249 & .158 & 3.211 & .001 \\
\hline Attitude towards environment and nature & .109 & .128 & .045 & .848 & .397 \\
\hline Attitude towards technological progress & .127 & .116 & .056 & 1.090 & .276 \\
\hline Attitude towards industrial production & .011 & .062 & .010 & .183 & .855 \\
\hline \multicolumn{6}{|l|}{ Control variables } \\
\hline Education & .364 & .164 & .112 & 2.219 & .027 \\
\hline Gender & -.088 & .187 & -.023 & -.469 & .640 \\
\hline Age & .005 & .007 & .044 & .765 & .445 \\
\hline Marital_Stat & .080 & .073 & .053 & 1.095 & .274 \\
\hline a. Dependent Variable: Cons_week & & & & & \\
\hline
\end{tabular}

sustainable and health food for consumers. This result is consistent with a recent study that reveals an ideological motivation for companies working with organic and sustainable food (Dalcin et al. 2014).

Although consumers' perception that companies in general do not consider the environment or consumers' needs, companies struggle to build a more sustainable supply chain, to develop their suppliers, producers and other important stakeholders for providing products in this market, that is seen as promising in the near future. Some bottlenecks, as the production of convenience sustainable products and logistics still need to be reversed. Decisions on location and material flow affect the environment and are crucial for the supply side (Beamon 2005), and this is a concern in the Brazilian scenario, not only for the food sector. Even in cases where all the processes and relationships are developed in a pro-environmental and social manner, there is no sustainable option and companies must use the existing modes of transportation (Bossle and Nascimento 2014).

Another interesting result is associated to the relationship among innovation, technology, and sustainability. At the same time that results brought what was found in previous work (Faucheux et al. 2006; Chang 2011; Kesidou and Demirel 2012), that eco-innovation can be an important tool for achievement of sustainable development, technology has come up as an important input to be more developed and employed in this market. Technology can increase innovation rates and improve sustainability, reducing losses and adding value to products (economic pillar), increasing supplying and production of healthier and sustainable food (social and environmental pillar).

In the consumers' side we also noticed a very positive attitude toward the relevance of technology as a determinant to improve the provision of healthier and more 
environmental friendly food. This can be a trend in Brazilian society that seems to be open for innovativeness and at the same time concerned with environmental sustainability (De Barcellos et al. 2012).

Even if consumers did not appear as an explicit motivation for the adoption of eco-innovation by companies, an innovation must be commercialized (Schumpeter 2008) and the importance of consumer awareness (Horbach 2008) is not neglected. Communication about health and sustainable aspects related to their products depend on clear legislation and labels, and difficulties in this area was a significant issue brought from the supply-side.This finding is aligned to previous research on functional food regulation in Brazil (Oliveira et al., 2014). In accordance with Azzone and Noci (1998), government must play a key role in turning regulations more complete and effective, and develop institutional campaigns to raise awareness in the market for this kind of product.

In relation to consumer awareness, we can assert that the studied sample is very conscious, presenting high scores for attitudes towards environment. This result ratify the good perspectives for this market in Brazil, since for Oltra and Jean (2009), consumers' assessment is critical for the adoption and success of eco-innovation.

The literature state a positive effect of personal values in consumers' pro-environmental behaviour towards the consumption of sustainable food (Grunert 1993; Grunert and Juhl, 1995; Hopper and Mccarl 1991; Schwartz 1992; Thøgersen and Beckmann 1997). Nevertheless, even if Brazilian consumers' collective values presented higher means than individualistic ones in this sample, apparently this has not actual influence in their behaviour in the market. The main factors that influenced consumption of eco-innovative food in this sample was the attitude towards eco-innovative food, attitudes towards food production, intention to buy eco-innovative food, frequency of purchase, Education and Adventure values, the later with a negative impact.

This later result apparently contradictory with literature on personal values is in consonance with De Barcellos et al. (2012) that found that consumers with Adventure values tend to prefer processed food instead of fresh products, maybe due to their willingness to have more time to their leisure. In this research, results from both exploratory and descriptive phase, demonstrated that consumers' current view about eco-innovative food available in the market, usually fruits and vegetables, tend to demand more time to prepare. In that sense, urge in the market the necessity of both fresh and more elaborated sustainable food, but in convenient packages, easy to handle and to prepare.

\section{Conclusion}

This paper can be divided into three research moments, in-depth interviews with producers, retailers and other representatives from the food chain, 42 exploratory interviews with consumers, and a Survey with 401 conscious consumers.

The study indicates that enterprise's mission and strategy are important drivers for the adoption of eco-innovations in food. Producers, retailers and other supply-side agents are very confident about their role in supplying eco-innovative food, such as organics. Another important role is related to the need to develop suppliers and to be mindful on what consumers are willing to buy/consume. Technology is an essential input for the 
supply side, and can act as an important driver to increase the supply of sustainable food, reduce losses, and, improve environmental sustainability.

Our study highlights the relevance of eco-innovation for the food industry especially in regard to the use of technology and innovation as a way to increase the healthiness and environmental characteristics in food products, and overall for the implementation of sustainable development. The importance of including environmental concepts in corporate strategy and the desirable potential to succeed in the market, which depends on consumer's evaluation, emphasize the importance of this study from production and consumption of environmental friendly products (Dangelico and Pujari 2010; Horbach 2008; Oltra and Jean 2009).

The survey indicates that consumers presented strong egalitarian values, such as benevolence and universalism, and very positive attitudes towards environment and technological progress, as well as a positive attitude and intention to buy ecoinnovative food. Additional findings points out towards a certain belief on behalf of Brazilian consumers that technology can be a determinant of relevant aspects of ecoinnovative foods.

The consumption of eco-innovative food is influenced by attitudes towards ecoinnovative food, as well as attitudes towards food production, intention to buy ecoinnovative food, frequency of purchase, Education and Adventure values. Although the impact of personal values on food consumption has been validated in other studies (Thøgersen and Beckmann 1997), in this Brazilian sample this influence, has not been proven, only adventure values significantly influence (negatively) eco-innovative food's consumption.

This research is of particular academic value, by adding empirical evidence about the relationships that rule how values and general attitudes influence attitudes towards eco-innovative food in the Brazilian food consumption context. Practical implications of this research is related to the need for companies to remain competitive and profitable, and innovation and environmental sustainability can be used as alternatives to mitigate environmental risks derived from the company's activities. Brazil is also a global food producer and changes in production and consumption patterns should be investigated as it might influence the mass scale production current paradigm.

Although the sample is not representative of the whole country, and results cannot be generalised it would be interested to apply the same approach in other industries, deeply analysing what drives companies to adopt eco-innovation and compare with the food sector. Another interesting research would be to investigate consumer's attitudes and intention to buy for other eco-innovative products, and test the influence from varied perspectives. 


\section{Acknowledgments}

The authors are grateful for the financial support provided by the following Brazilian Agencies: National Council for Scientific and Technological Development (CNPq) and CAPES Foundation for developing this research.

\section{Author details}

${ }^{1}$ Federal University of Rio Grande do Sul, Post-Graduate Programme in Management (PPGA/UFRGS) - Porto Alegre, (90010-460) RS, Brazil. ${ }^{2}$ UNISINOS, Post-Graduate Programme in Management - São Leopoldo, (93022-000) RS, Brazil.

Received: 23 July 2014 Accepted: 12 December 2014

Published online: 29 January 2015

\section{References}

Ajzen I (1988) Attitudes, personality, and behavior. Dorsey Press, Chicago

Asheim BT, Gertler MS (2005) The geography of innovation: regional innovation systems. In: Fagerberg J, Mowery D, Nelson R (eds) The Oxford Handbook of Innovation. Oxford University Press, Oxford

Azzone G, Noci G (1998) Seeing ecology and "green" innovations as a source of change. J Organ Change Manag 11(2):94-111

Balderjahn I, Peyer M, Paulssen M (2013) Consciousness for fair consumption: conceptualization, scale development and empirical validation. Int J Consum Stud 37:546-555

Brazilian Food Industry Association ABIA (2014). http://www.abia.org.br/default.asp. Accessed 5 Jan 2014

Brazilian Institute of Geography and Statistics - IBGE (2013). http://www.ibge.gov.br/home/. Accessed 05 Jan 2013 Beamon BM (2005) Environmental and sustainability ethics in supply chain management. Sci Eng Ethics 11:221-234 Beckmann SC, Brokmose S, Lind RL (2001) Danish consumers and organic foods. Copenhagen Business School, Copenhagen Bocken NMP, Allwood JM, Willey AR, King JMH (2011) Development of an eco-ideation tool to identify stepwise greenhouse gás emissions reduction options for consumer goods. J Cleaner Prod 19:1279-1287

Bossle MB, Nascimento LFM (2014) As relações interorganizacionais na rede Justa Trama como um fator de sucesso na produção e comercialização dos produtos do algodão ecológico. Rev Metropol Sustentab 4(2):64-81

Carrillo-Hermosilla J, Del Río P, Könnölä T (2010) Diversity of eco-innovations: reflections from selected case studies. J Cleaner Prod 18:1073-1083

Chang C-H (2011) The influence of corporate environmental ethics on competitive advantage: the mediation role of green innovation. J Bus Ethics 104:361-370

Dalcin D, De Souza ARL, De Freitas JB, Padula AD, Dewes H (2014) Organic products in Brazil: from an ideological orientation to a market choice. Br Food J 116(12):1998-2015

Dangelico RM, Pujari D (2010) Mainstreaming green product innovation: why and how companies integrate environmental sustainability. J Bus Ethics 95:471-486

De Barcellos MD, Perin MG, Perez-Cueto FJA, Saab MSM, Grunert KG (2012) Consumers' values and attitudes and their relation to the consumption of pork products: a study from Q-PorkChains in Brazil. J Chain Netw Sci (Print) 12:41-54

Demirel P, Kesidou E (2011) Stimulating different types of eco-innovation in the UK: government policies and firm motivations. Ecol Econ 70:1546-1557

Dosi G (1988) The nature of the innovative process. In: Dosi G et al (eds) Technical change and economic theory. Pinter Publisher, London and New York

Dunlap RE, Van Liere KD, Mertig AG (2000) Measuring endorsement of the new ecological paradigm: a revised NEP scale. J Soc Issues 56(3):425-442

Ettlie JE (1983) Organizational policy and innovation among suppliers to the food processing sector. Acad Manage J 26(1):27-44

Fagerberg J (2005) Innovation: a guide to the literature. In: Fagerberg J, Mowery D, Nelson R (eds) The Oxford handbook of innovation. Oxford University Press, Oxford

Faucheux S, Hue C, Nicolai I (2006) L'éco-innovation: une opportunité pour l'avenir du développement durable? Quelques éléments de bilan et de prospective aux niveaux européen et international. Ateliers L'Ethique 1(2):41-56

Grunert KC, Jeppesen LF, Jespersen KR, Sonne A-M (2005) Market orientation of value chains: a conceptual framework based on four case studies from the food industry. Eur J Mark 39(5/6):428-455

Grunert KG, Brunsø K, Bisp S (1993) Food-related life style: development of a cross-culturally valid instrument for market surveillance. Aarhus, Denmark: MAPP; MAPP working paper 12 (project 14)

Grunert SC (1993) Green consumerism in Denmark: some evidence from the Oko foods-project. Der Markt 32(3):140-151

Grunert SC, Juhl HJ (1995) Values, environmental attitudes, and buying of organic foods. J Econ Psychol 16:39-62

Hair JF, Tatham RL, Anderson RE, Black W (1998) Multivariate data analysis, 5th edn. Prentice Hall, Upper Saddle River, New Jersey.

Halila F, Rundquist J (2011) The development and market success of eco-innovations: a comparative study of eco-innovations and "other" innovations in Sweden. Eur J Innov Manag 14(3):278-302

Hamstra AM (1991) Biotechnology in food stuffs - towards a model of consumer acceptance. The SWOKA Institute, The Hague Hopper JR, Mccarl N (1991) Recycling as altruistic behavior. Normative and behavioral strategies to expand participation in a community recycling program. Environ Behav 23:195-220

Horbach J (2008) Determinants of environmental innovation - new evidence from German panel data sources. Res Policy 37:163-173

Kesidou E, Demirel P (2012) On the drivers of eco-innovations: empirical evidence from the UK. Res Policy 41:862-870 Korhonen J (2001) Four ecosystem principles for an industrial ecosystem. J Cleaner Prod 9:253-259

Krystallis A, Grunert KG, De Barcellos MD, Perrea T, Werbeke W (2012) Consumer attitudes towards sustainability aspects of food production. J Mark Manag 28(3-4):334-372

Lindeman M, Väänänen M (2000) Measurement of ethical food choice motives. Appetite 34:55-59 
Oliveira G, Vieira LM, Hoppe A, de Barcellos MD (2014) Institutional barriers for food innovation: a study of the Brazilian functional food industry. J Oper Suppl Chain Manage (JOSCM) 7:1-14

Oltra V, Jean MS (2009) Sectoral systems of environmental innovation: an application to the French automotive industry. Technol Forecast Soc Change 76:567-583

Organization for Economic Co-operation and Development OECD, 2009. Sustainable manufacturing and eco-innovation: towards a Green economy. Policy Brief June 2009

Perrea T, Grunert K, Krystallis A, Zhou Y, Huang G, Hue Y (2014). Testing and Validation of a Hierarchical Values-Attitudes Model in the Context of Green Food in China. In: Asia Pacific Journal of Marketing and Logistics, 26(2):296-314. http://pure.au.dk/portal/en/publications/testing-and-validation-of-a-hierarchical-valuesattitudes-model-in-thecontext-of-green-food-in-china(248f6c11-fce2-4de5-b13a-871d799b2f6f).html

Portilho F (2005) Sustentabilidade ambiental, consumo e cidadania. Cortez, São Paulo, Brazi

Rennings K (2000) Redefining innovation - eco-innovation research and the contribution from ecological economics. Ecol Econ 32:319-332

Roberts JA, Bacon DR (1997) Exploring the subtle relationships between environmental concern and ecologically conscious consumer behavior. J Bus Res 40:79-89

Schaltegger S, Wagner M (2011) Sustainable entrepreneurship and sustainability innovation: categories and interactions. Bus Strategy Environ 20:222-237

Schumpeter J (2008) The theory of economic development, 14th edn. Transaction, New Jersey

Schwartz SH (1992) Universals in the content and structure of values: theory and empirical tests in 20 countries. In: Zanna M (ed) Advances in experimental social psychology, vol 25. Academic Press, New York

Steg L, Vlek C (2009) Encouraging pro-environmental behaviour: an integrative review and research agenda. J Environ Psychol 29:309-317

Thøgersen J, Beckmann SC (1997) Values and attitude formation towards emerging attitude objects: from recycling to general waste minimizing behavior. In: Brucks M, Maclnnis DJ (eds) Advances in Consumer Research

\section{Submit your manuscript to a SpringerOpen ${ }^{\circ}$ journal and benefit from:}

- Convenient online submission

- Rigorous peer review

- Immediate publication on acceptance

- Open access: articles freely available online

- High visibility within the field

- Retaining the copyright to your article

Submit your next manuscript at $\boldsymbol{\nabla}$ springeropen.com 